\title{
Realizacja Regionalnych Inwestycji Terytorialnych na przykładzie subregionu ostrołęckiego
}

\author{
Justyna Klimkowska, Katarzyna Pawłowska
}

\section{STRESZCZENIE}

Niniejszy artykuł poświęcony jest analizie stanu realizacji projektów w ramach Regionalnych Inwestycji Terytorialnych (RIT) na przykładzie subregionu ostrołęckiego. RIT to nowy mechanizm finansowania zaproponowany przez Samorząd Województwa Mazowieckiego na perspektywę finansową 20142020, mający za zadanie wspomaganie rozwoju obszarów wymagających wsparcia oraz wzmacnianie ich potencjałów poprzez rozwijanie funkcji społeczno-gospodarczych. Mechanizm ten powstał w wyniku zmiany w modelu polityki spójności Unii Europejskiej, która ma mieć ukierunkowanie terytorialne.

W pierwszej części artykułu przedstawione zostały podstawowe informacje na temat samego instrumentu RIT oraz sposobu jego realizacji w województwie mazowieckim. Następnie zaprezentowano krótką charakterystykę subregionu ostrołęckiego, zawierającą informacje o zidentyfikowanych w Planie Inwestycyjnym dla Miasta Ostrołęki i subregionu ostrołęckiego potencjałach i potrzebach inwestycyjnych obszaru. W dalszej części artykułu, na podstawie danych pozyskanych z Departamentu Rozwoju Regionalnego i Funduszy Europejskich Urzędu Marszałkowskiego Województwa Mazowieckiego, informacji zawartych w Planie Inwestycyjnym dla Miasta Ostrołęki i subregionu ostrołęckiego oraz innych dostępnych źródeł, dokonano podsumowania dotychczasowej realizacji projektów w ramach mechanizmu w subregionie ostrołęckim. Ponadto, porównano subregiony województwa mazowieckiego w zakresie łącznej liczby i wartości podpisanych umów na dofinansowanie zaplanowanych przedsięwzięć.

Wyniki przeprowadzonej analizy wykazały, że funkcjonowanie instrumentu RIT przynosi korzystne rezultaty zarówno w subregionie ostrołęckim, jak i w całym województwie mazowieckim. Mechanizm ten wspomaga rozwój obszarów w różnych dziedzinach, m.in.: infrastruktura drogowa, przygotowanie terenów pod działalność gospodarczą, rewitalizacja i ochrona dziedzictwa kulturowego, infrastruktura zdrowotna oraz ograniczanie niskiej emisji. Działanie mechanizmu w kolejnych perspektywach finansowych z pewnością przyczyniłoby się do dalszego wzmacniania procesów rozwojowych w subregionach województwa mazowieckiego.

Słowa kluczowe: Regionalne Inwestycje Terytorialne, plan inwestycyjny, subregion ostrołęcki

\section{Wstęp}

Na przestrzeni ostatnich lat nastąpiła zmiana podejścia w polityce spójności Unii Europejskiej. Wpłynęły na to zmieniające się wyzwania i uwarunkowania rozwojowe, w tym narastające pogłębianie i poszerzanie procesu integracji europejskiej. Szczególnego znaczenia nabrała polityka ukierunkowana terytorialnie, która opiera się na wykorzystaniu potencjałów endogenicznych poszczególnych obszarów oraz ich specyfik. Takie podejście w polityce spójności ma się przyczynić do pełniejszego wykorzystania możliwości rozwojowych całej Unii Europejskiej [Słupińska 2013, s. 9]. Planowanie procesów rozwojowych zgodnie z tą polityką powinno mieć charakter zintegrowany, czyli opierać się na dopasowaniu interwencji 
do potrzeb obszarów określonych geograficznie, które łączą wspólne perspektywy rozwojowe oraz powiązania funkcjonalne. W celu realizacji polityki rozwoju ukierunkowanej terytorialnie, w perspektywie finansowej na lata 2014-2020, rozpoczęły funkcjonowanie nowe instrumenty finansowe - w tym w województwie mazowieckim - RIT. Celem niniejszego artykułu jest przybliżenie istoty RIT oraz podsumowanie dotychczasowej realizacji projektów w ramach tego instrumentu w subregionie ostrołęckim.

\section{Podstawowe informacje o RIT}

RIT jest to mechanizm finansowania i rozwoju terytorialnego stworzony przez Samorząd Województwa Mazowieckiego ${ }^{1}$, realizowany w ramach Regionalnego Programu Operacyjnego Województwa Mazowieckiego na lata 2014-2020² (RPO WM 2014-2020). Jest on skierowany do miast regionalnych (Płock, Radom) i subregionalnych (Ciechanów, Ostrołęka, Siedlce) oraz ich obszarów funkcjonalnych. W swoim założeniu ma wspierać Obszary Strategicznej Interwencji (OSI), które zostały wskazane w Strategii Rozwoju Województwa Mazowieckiego do 2030 roku. Innowacyjne Mazowsze. RIT bazuje na zasadach właściwych dla Zintegrowanych Inwestycji Terytorialnych (ZIT), które są instrumentami rozwoju terytorialnego, wdrażanymi obligatoryjnie na terenie miast wojewódzkich i obszarów powiązanych z nimi funkcjonalnie.

Głównym celem utworzenia tego mechanizmu jest skuteczniejsze wykorzystanie środków w ramach polityki spójności poprzez uwzględnienie wymiaru przestrzennego, co pozwoli na spójne, skoordynowane i zintegrowane działania prorozwojowe na obszarze danego subregionu. Za pomocą tego instrumentu jednostki samorządu terytorialnego realizują komplementarne przedsięwzięcia łączące wsparcie z kilku osi priorytetowych RPO WM 2014-2020, finansowanych z dwóch funduszy, tj. Europejskiego Funduszu Rozwoju Regionalnego (EFRR) i Europejskiego Funduszu Społecznego (EFS).

Inwestycje w ramach RIT są realizowane na zasadzie współpracy jednostek samorządu terytorialnego i wojewódzkich jednostek organizacyjnych funkcjonujących na obszarze subregionu, które są zobowiązane do zawarcia dowolnej formy partnerstwa, np. stowarzyszenia, związku międzygminnego, porozumienia międzygminnego lub podpisania listu intencyjnego. Funkcję koordynatora instrumentu w subregionie pełni Lider, którym z zasady jest główne miasto na danym obszarze. W subregionie ostrołęckim Liderem jest Miasto Ostrołęka. Lider wraz z Partnerami, na zasadzie współpracy, opracowują Plan Inwestycyjny. Do-

\footnotetext{
${ }^{1}$ Uchwała nr 496/338/14 Zarządu Województwa Mazowieckiego z dnia 8 kwietnia 2014 r. w sprawie przyjęcia projektu Regionalnego Programu Operacyjnego Województwa Mazowieckiego na lata 20142020 (wersja 1.3).

${ }^{2}$ Regionalny Program Operacyjny Województwa Mazowieckiego na lata 2014-2020 - jeden z 16 programów operacyjnych w Polsce, zarządzanych i wdrażanych na poziomie regionalnym. Stanowi jeden z instrumentów realizacji Umowy Partnerstwa - dokumentu określającego strategię interwencji funduszy europejskich w ramach trzech polityk unijnych w Polsce w latach 2014-2020. Głównym celem RPO WM 2014-2020 jest „Inteligentny, zrównoważony rozwój zwiększający spójność społeczną i terytorialną przy wykorzystaniu potencjału mazowieckiego rynku pracy".
} 
kument jest podstawą do wdrażania mechanizmu RIT w subregionie - warunkuje alokację środków finansowych i realizację projektów. Plan Inwestycyjny zawiera diagnozę obszaru (w tym potencjały i problemy rozwojowe) oraz projekty wiodące i towarzyszące. Realizacja projektów wpłynie na przyspieszenie procesów rozwojowych oraz na przeciwdziałanie zdiagnozowanym problemom i potrzebom subregionu. Zaplanowane projekty powinny mieć jak najszersze oddziaływanie terytorialne i poprawiać integrację przestrzenna, m.in. poprzez wzmocnienie powiązań funkcjonalnych między miastami regionalnymi i subregionalnymi a pozostałymi terenami w danym subregionie, poprawę dostępności obszaru oraz zwiększenie dostępu do usług tworząc warunki do jego rozwoju społeczno-gospodarczego.

Możliwość dofinansowania projektów jest oceniana w trybie konkursowym. Otrzymanie wsparcia jest uwarunkowane uzyskaniem pozytywnej oceny, zgodnie z kryteriami przyjętymi przez Komitet Monitorujący RPO WM 2014-2020. Po uzyskaniu pozytywnej oceny, podpisywane są umowy na realizację projektów z poszczególnymi beneficjentami wchodzącymi w partnerstwo tworzące RIT danego subregionu.

Samorząd Województwa Mazowieckiego jest instytucją zarządzającą mechanizmem RIT. Do jego kompetencji w tym zakresie należy m.in. wybór projektów do dofinansowania, zlecanie płatności na rzecz beneficjentów, weryfikacja poprawności ponoszonych przez nich wydatków, monitorowanie postępów realizacji programu i weryfikacja osiąganych celów.

\section{Subregion ostrołęcki jako obszar realizacji RIT}

Realizacja projektów w subregionie ostrołęckim odbywa się w obszarze administracyjnym Miasta Ostrołęki oraz powiatów: ostrołęckiego, wyszkowskiego, makowskiego, przasnyskiego i ostrowskiego. Tereny te zaliczają się do ostrołęcko-siedleckiego OSI wyznaczonego w Strategii Rozwoju Województwa Mazowieckiego do 2030 roku. Innowacyjne Mazowsze.

Subregion ostrołęcki to obszar typowo rolniczy, na którym znajdują się wyspecjalizowane obszary produkcji rolniczej, stanowiące bazę surowcową dla przetwórstwa rolno-spożywczego. Dostępne są również złoża surowców naturalnych dla budownictwa i drogownictwa, bogate i różnorodne tradycje kulturowe oraz możliwość rozwoju agroturystyki na bazie funkcjonujących gospodarstw rolnych.

Pomimo znacznego potencjału subregionu istnieje potrzeba podniesienia walorów społecznych, gospodarczych i środowiskowych. Konieczna jest poprawa sieci komunikacyjnej polegająca na przebudowie i rozbudowie dróg wojewódzkich i powiatowych, co zwiększy dostępność całego subregionu. Dużym problemem, głównie większych miast subregionu, jest zanieczyszczenie środowiska, a w związku z tym konieczny jest rozwój mobilności miejskiej, a także termomodernizacja budynków użyteczności publicznej. Jednym z ważniejszych aspektów wymagających wsparcia jest poprawa dostępu do nowoczesnych metod leczenia, poprawy jakości usług medycznych oraz doposażenia szpitali w Makowie Mazowieckim, Przasnyszu, Ostrołęce i Wyszkowie. Konieczna jest także rewitalizacja obszarów zmarginalizowanych poprzez tworzenie instytucji wpływających na wzrost przedsiębiorczości i aktyw- 
ności inwestycyjnej. W powiecie przasnyskim istnieje potrzeba uzbrojenia terenów docelowo przeznaczonych pod inwestycje. Istotne jest również wykorzystanie potencjału kulturowego subregionu poprzez ochronę obiektów zabytkowych, nadanie im nowych funkcji i rewitalizację, co zwiększy zainteresowanie turystyczne oraz podniesie standard edukacji kulturalnej.

Powyższa charakterystyka subregionu, uwzględniająca jego potencjały i problemy, wynika $\mathrm{z}$ informacji zawartych $\mathrm{w}$ dokumentach strategicznych oraz $\mathrm{w}$ Planie Inwestycyjnym dla Miasta Ostrołęki i subregionu ostrołęckiego, stanowiącego podstawę realizacji RIT.

\section{Realizacja projektów ujętych w Planie Inwestycyjnym dla miasta Ostrołęki i subregionu ostrołęckiego}

W Planie Inwestycyjnym dla miasta Ostrołęki i subregionu ostrołęckiego, w odpowiedzi na zidentyfikowane wyzwania, problemy rozwojowe i potencjały, zaproponowano projekty przewidziane do realizacji w ramach RIT. Realizacja tych projektów ma przyczynić się do przyspieszenia procesów rozwojowych w subregionie oraz do przeciwdziałania negatywnym trendom, co doprowadzi do zmniejszenia dysproporcji rozwojowych między subregionem ostrołęckim a aglomeracją warszawską. Koncepcje projektów wpisanych do Planu Inwestycyjnego są wynikiem ścisłej współpracy Lidera i Partnerów subregionu ostrołęckiego.

Plan Inwestycyjny dla miasta Ostrołęki i subregionu ostrołęckiego był kilkukrotnie modyfikowany ze względu na ujmowanie w jego zapisach nowych projektów. Aktualna wersja dokumentu została przyjęta uchwałą Zarządu Województwa Mazowieckiego z dnia 12 czerwca 2018 r. ${ }^{3}$

Dokument przewiduje realizację dwóch Projektów wiodących, czyli tzw. „projektów twardych” finansowanych z EFRR, oraz Projektów towarzyszących, czyli „projektów miękkich" finansowanych ze środków EFS.

Zgodnie ze zidentyfikowanymi wspólnymi problemami, celami oraz zasięgiem inwestycji, wskazani zostali Partnerzy dla Projektów Wiodących (ryc. 1). Partnerami Projektów towarzyszących zostały wszystkie gminy z powiatu ostrołęckiego, makowskiego, ostrowskiego, przasnyskiego i wyszkowskiego.

Projekty wiodące stanowią zespół zintegrowanych przedsięwzięć (wiązki projektów), wpisujących się w priorytety inwestycyjne zawarte w RPO WM 2014-2020. Projekty wiodące wskazane do realizacji w mieście Ostrołęka i subregionie ostrołęckim to:

- I - Zrównoważony rozwój miasta Ostrołęki i subregionu ostrołęckiego poprzez poprawę zewnętrznej i wewnętrznej dostępności jego potencjału: gospodarczego, społecznego i środowiskowo-rekreacyjnego;

- II - Poprawa jakości życia mieszkańców subregionu ostrołęckiego poprzez ograniczenie niskiej emisji oraz zwiększenie dostępności i jakości usług publicznych, w tym usług zdrowotnych i profilaktyki zdrowotnej.

\footnotetext{
${ }^{3}$ Uchwała nr 951/347/18 Zarządu Województwa Mazowieckiego z dnia 12 czerwca 2018 r. zmieniająca uchwałę w sprawie przyjęcia dokumentu pn.: „Plan Inwestycyjny dla Miasta Ostrołęki i Subregionu Ostrołęckiego".
} 
W zakres I Projektu wiodącego wchodzą inwestycje dotyczące infrastruktury drogowej, przygotowania terenów pod działalność gospodarczą oraz rewitalizacji i ochrony dziedzictwa kulturowego. W zakres II Projektu wiodącego wpisują się przedsięwzięcia z dziedziny

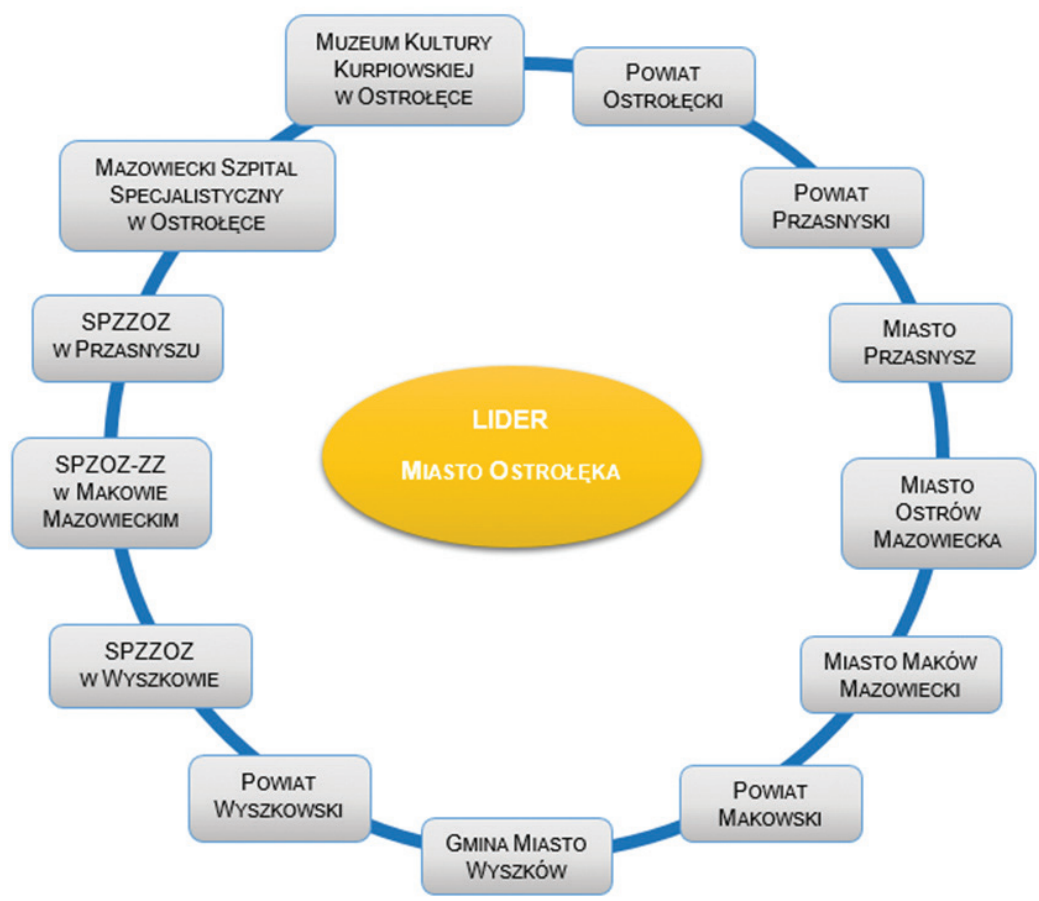

Ryc. 1. Partnerzy dla Projektów wiodących w subregionie ostrołęckim

Źródło: opracowanie własne na podstawie Planu Inwestycyjnego dla miasta Ostrołęki i subregionu ostrołęckiego

infrastruktury zdrowotnej i ograniczania niskiej emisji. Łącznie w ramach dwóch Projektów wiodących przewidziano realizację 46 inwestycji. Najwięcej inwestycji dotyczy przebudowy infrastruktury drogowej, co stanowi odpowiedź na jedną z najważniejszych potrzeb subregionu ostrołęckiego, jaką jest poprawa dostępności komunikacyjnej.

Do każdego Projektu wiodącego zostały przypisane Projekty towarzyszące, których zadaniem jest wspieranie przedsięwzięć infrastrukturalnych w aspekcie społecznym. Projekty towarzyszące wskazane w Planie Inwestycyjnym dotyczą:

- poprawy jakości funkcjonowania młodzieży zagrożonej wykluczeniem społecznym,

- wspierania funkcjonowania rodzin dysfunkcyjnych,

- profilaktyki cukrzycy,

- edukacji młodzieży,

- podniesienia aktywności zawodowej osób dorosłych. 
Do dnia 30.04.2019 r. na terenie subregionu ostrołęckiego podpisano łącznie 26 umów na realizację inwestycji w ramach $\mathrm{RIT}^{4}-16$ z nich wchodzi w zakres I Projektu wiodącego, pozostałe 10 umów dotyczy II Projektu wiodącego. Wartość tych projektów opiewa na blisko 323,3 mln zł. Zrealizowanych zostało 12 projektów (ryc. 2), a 14 jest w trakcie realizacji ${ }^{5}$. Inwestycje te wpisują się w następujące działania RPO WM 2014-2020, tj.:

- $\quad 3.1$ Poprawa rozwoju MŚP na Mazowszu (1 projekt),

- $\quad 4.2$ Efektywność energetyczna (2 projekty),

- $\quad 4.3$ Redukcja emisji zanieczyszczeń powietrza (3 projekty),

- $\quad 5.3$ Dziedzictwo kulturowe (3 projekty),

- $\quad 6.1$ Infrastruktura ochrony zdrowia (5 projektów),

- $\quad 6.2$ Rewitalizacja obszarów zmarginalizowanych (3 projekty),

- $\quad 7.1$ Infrastruktura drogowa (9 projektów).

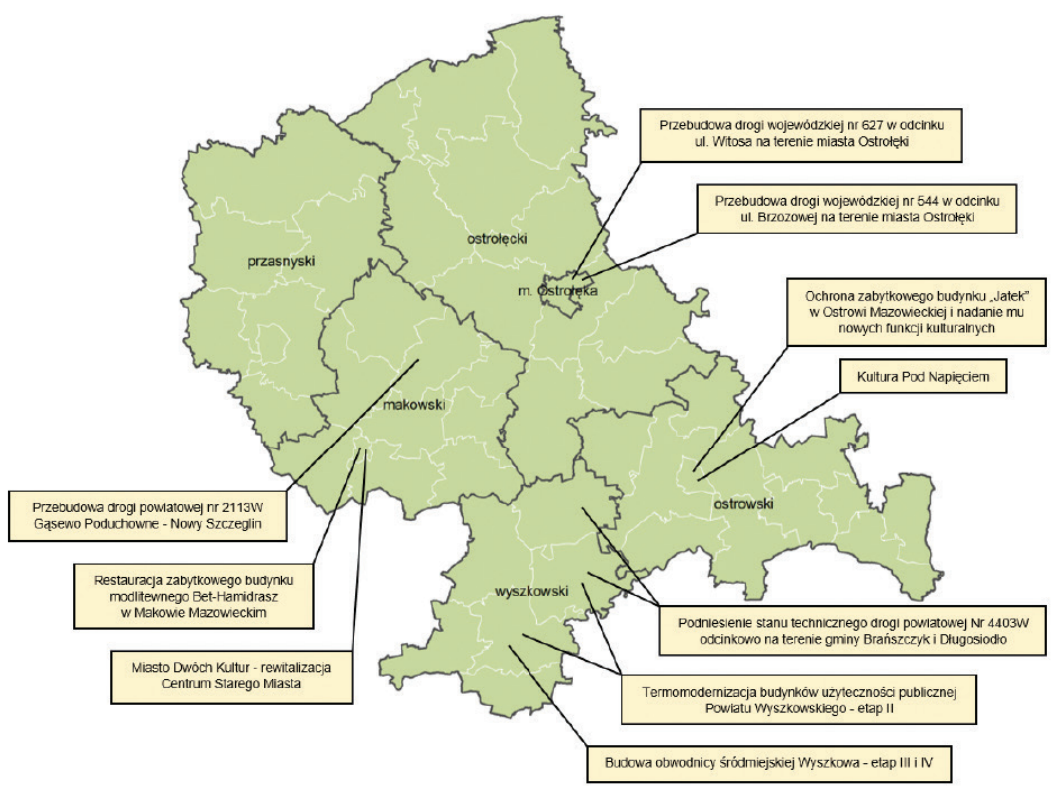

Ryc. 2. Inwestycje zrealizowane w subregionie ostrołęckim

Źródło: opracowanie własne na podstawie danych z Departamentu Rozwoju Regionalnego i Funduszy Europejskich Urzędu Marszałkowskiego Województwa Mazowieckiego oraz informacji ze stron internetowych, stan na 30.04.2019 r.

\footnotetext{
${ }^{4}$ Dane pozyskane z Departamentu Rozwoju Regionalnego i Funduszy Europejskich Urzędu Marszałkowskiego Województwa Mazowieckiego.

${ }^{5}$ Stopień realizacji poszczególnych inwestycji był weryfikowany na podstawie informacji ze stron internetowych.
} 
Największą liczbę umów o dofinansowanie projektów podpisano w powiecie wyszkowskim - 8 umów. Inwestycje te dotyczą efektywności energetycznej, redukcji emisji zanieczyszczeń powietrza, infrastruktury drogowej i infrastruktury ochrony zdrowia. Zrealizowanych zostało 5 projektów, które obejmują termomodernizacje budynków użyteczności publicznej w gminach Brańszczyk i Długosiodło, podniesienie stanu technicznego drogi powiatowej nr 4403W odcinkowo na terenie gminy Brańszczyk i Długosiodło oraz budowę obwodnicy śródmiejskiej Wyszkowa etap III i IV. W trakcie realizacji są 3 projekty dotyczące rozwoju zrównoważonej multimodalnej mobilności miejskiej w Wyszkowie i doposażenia szpitala w Wyszkowie.

$\mathrm{W}$ powiecie makowskim podpisano umowy na 4 inwestycje z zakresu dziedzictwa kulturowego, infrastruktury ochrony zdrowia, rewitalizacji oraz infrastruktury drogowej. Realizacja 3 z nich dobiegła już końca. W trakcie realizacji jest 1 przedsięwzięcie dotyczące modernizacji infrastruktury i wyposażenia medycznego szpitala w Makowie Mazowieckim. Inwestycje zakończone w ramach RIT w powiecie makowskim to: restauracja zabytkowego budynku modlitewnego Bet-Hamidrasz w Makowie Mazowieckim, rewitalizacja Centrum Starego Miasta w Makowie Mazowieckim oraz przebudowa drogi powiatowej nr 2113 W Gąsewo Poduchowne - Nowy Szczeglin.

$\mathrm{W}$ powiecie ostrowskim zostały podpisane 3 umowy o dofinansowanie. Zrealizowano 2 projekty z zakresu dziedzictwa kulturowego pt. „Ochrona zabytkowego budynku Jatek w Ostrowi Mazowieckiej i nadanie mu nowych funkcji kulturalnych” i „Kultura Pod Napięciem”, polegająca na adaptacji dwóch istniejących obiektów na cele kulturalne. Projekt, który jest nadal realizowany, dotyczy budowy ścieżek rowerowych w Ostrowi Mazowieckiej.

$\mathrm{Z}$ terenu powiatu przasnyskiego 5 projektów otrzymało dofinansowanie $\mathrm{w}$ ramach RIT. Wszystkie są w trakcie realizacji i dotyczą: kompleksowego uzbrojenia terenów inwestycyjnych w północnej części powiatu, podniesienia poziomu opieki zdrowotnej szpitala w Przasnyszu, prac remontowych budynku Starostwa Powiatowego w Przasnyszu, rewitalizacji terenów w Zdziwóju Nowym i Zdziwóju Starym oraz budowy układu drogowo-infrastrukturalnego terenów inwestycyjnych Przasnyskiej Strefy Gospodarczej - Podstrefa w Chorzelach.

W mieście Ostrołęka podpisano 5 umów o dofinansowanie inwestycji. Projekty te obejmują działania z zakresu redukcji emisji zanieczyszczeń powietrza, infrastruktury ochrony zdrowia oraz infrastruktury drogowej. Zrealizowano 2 projekty, które dotyczą przebudowy dróg wojewódzkich: nr 627 na odcinku ul. Witosa oraz nr 544 na odcinku ul. Brzozowej. Pozostałe 3 inwestycje są w trakcie realizacji, w tym przebudowa drogi wojewódzkiej nr 627 w odcinku ul. Ostrowskiej i ul. Słowackiego oraz poprawa dostępu do usług publicznych w zakresie rehabilitacji kardiologicznej w ostrołęckim szpitalu. W ramach nadal realizowanego projektu pn. „Ograniczenie emisji zanieczyszczeń powietrza poprzez zrównoważony rozwój mobilności miejskiej na terenie Ostrołęki” została wykonana m.in. przebudowa ulicy Dobrzańskiego.

W powiecie ostrołęckim podpisano 1 umowę na realizację inwestycji. Projekt pt. „Podniesienie stanu technicznego drogi powiatowej nr 4403W na terenie gminy Goworowo, powiatu 
ostrołęckiego w ramach poprawy jakości połączenia subregionalnej struktury komunikacyjnej z siecią TEN-T" jest w trakcie realizacji.

Największą inwestycją zrealizowaną do tej pory w subregionie ostrołęckim jest przedsięwzięcie pn.: „Budowa obwodnicy śródmiejskiej Wyszkowa - etap III i IV”, które bezpośrednio wpisuje się w cel główny Planu Inwestycyjnego: poprawa zewnętrznej $i$ wewnętrznej dostępności potencjału miasta Ostrołęki i subregionu ostrołęckiego poprzez jego rewitalizację oraz podniesienie walorów użyteczności gospodarczej, społecznej i środowiskowo-rekreacyjnej. Inwestycja polegała na rozbudowie drogi $440584 \mathrm{~W}$, która stanowi bezpośrednie połączenie drogi ekspresowej S8 z drogą krajową DK62 Strzelno - Siemiatycze, przecinające drogę wojewódzką nr 618 Gołymin - Pułtusk - Wyszków. Ponadto, obwodnica przebiega przez tereny inwestycyjne zlokalizowane w północno-zachodniej części miasta Wyszkowa, co znacznie zwiększa ich dostępność, a tym samym atrakcyjność dla potencjalnych inwestorów. Całkowity koszt zrealizowanej inwestycji wyniósł prawie 32,8 mln zł, z czego dofinansowanie stanowiło niemal 17,6 mln zł.

Istotna, zrealizowaną inwestycją w subregionie ostrołęckim jest również projekt pn.: „Przebudowa drogi wojewódzkiej nr 627 w odcinku ul. Witosa na terenie miasta Ostrołęki”. Droga ta jest jedną z ważniejszych w subregionie, bezpośrednio łączy się z DK61. Całkowita wartość przedsięwzięcia to ponad 6,1 mln zł, z czego dofinansowanie stanowiło prawie 4,8 mln zł.

Znaczącą inwestycją z zakresu rewitalizacji obszarów zmarginalizowanych była realizacja projektu pn.: „Miasto Dwóch Kultur - rewitalizacja Centrum Starego Miasta” w Makowie Mazowieckim. Zakres prac objął m.in.: remont, budowę i przebudowę nawierzchni rynku, budowę fontanny, zagospodarowanie przestrzeni zielenią i obiektami małej architektury oraz prace budowlane i restauratorskie kamienicy. Na zrewitalizowanym obszarze prowadzona jest działalność o charakterze handlowo-usługowym, a także organizowane są wydarzenia kulturalne ${ }^{6}$. Wartość inwestycji to niemal 14,7 mln zł, z czego dofinansowanie to ponad $7 \mathrm{mln}$ zł.

\section{RIT w subregionie ostrołęckim na tle innych subregionów województwa mazowieckiego}

Instrument RIT realizowany jest nie tylko w subregionie ostrołęckim. W subregionach ciechanowskim, płockim, radomskim i siedleckim również podpisanych zostało wiele umów na realizację inwestycji $\mathrm{w}$ ramach tego mechanizmu. Na podstawie danych otrzymanych z Departamentu Rozwoju Regionalnego i Funduszy Europejskich dokonano zestawienia liczby i wartości podpisanych umów w pięciu subregionach województwa mazowieckiego (tabela 1).

\footnotetext{
${ }^{6}$ Na podstawie: mapadotacji.gov.pl
} 
Tabela 1. Zestawienie podpisanych umów w poszczególnych subregionach województwa mazowieckiego

\begin{tabular}{|c|c|c|c|c|c|c|}
\hline \multirow[t]{2}{*}{ Działanie } & \multicolumn{5}{|c|}{ Subregiony } & \multirow{2}{*}{$\begin{array}{l}\text { Liczba podpisanych } \\
\text { umów w poszczegól- } \\
\text { nych działaniach }\end{array}$} \\
\hline & 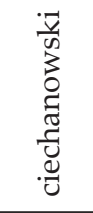 & 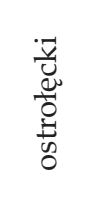 & $\begin{array}{l}\vec{v} \\
\frac{\vec{u}}{2} \\
\frac{0}{2}\end{array}$ & 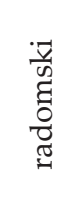 & $\frac{\sqrt{y}}{\frac{d}{0}}$ & \\
\hline 2.1 & - & - & - & 4 & - & 4 \\
\hline 3.1 & - & 1 & 1 & - & - & 2 \\
\hline 4.2 & - & 2 & - & 2 & - & 4 \\
\hline 4.3 & 4 & 3 & 2 & - & 7 & 16 \\
\hline 5.3 & - & 3 & - & - & - & 3 \\
\hline 6.1 & 1 & 5 & 2 & 3 & 6 & 17 \\
\hline 6.2 & 1 & 3 & 2 & 4 & - & 10 \\
\hline 7.1 & 18 & 9 & 3 & - & 12 & 42 \\
\hline $\begin{array}{l}\text { Liczba } \\
\text { podpisanych } \\
\text { umów }\end{array}$ & 24 & 26 & 10 & 13 & 25 & 98 \\
\hline $\begin{array}{l}\text { Wartość } \\
\text { projektów } \\
\text { ogółem (mln zł) }\end{array}$ & 184,1 & 323,3 & 360,1 & 97,6 & 283,4 & 1248,4 \\
\hline
\end{tabular}

Źródło: opracowanie własne na podstawie danych otrzymanych z Departamentu Rozwoju Regionalnego i Funduszy Europejskich Urzędu Marszałkowskiego Województwa Mazowieckiego, stan na 30.04.2019 r.

W subregionach ciechanowskim, ostrołęckim, płockim, radomskim i siedleckim łącznie podpisano niemal 100 umów. Dotyczą one działań z zakresu e-usług, poprawy rozwoju MŚP na Mazowszu, efektywności energetycznej, redukcji emisji zanieczyszczeń powietrza, dziedzictwa kulturowego, rewitalizacji obszarów zmarginalizowanych oraz infrastruktury drogowej. Łączna wartość inwestycji realizowanych w ramach mechanizmu to ponad 1,2 mld zł.

Najwięcej umów podpisano w subregionie ostrołęckim. Projekty zrealizowane i przewidziane do realizacji na tym obszarze są najbardziej zróżnicowane i wpisują się w największą liczbę działań RPO WM 2014-2020. Wartość podpisanych umów na realizację inwestycji w subregionie ostrołęckim stanowi ponad 1/4 całkowitej wartości projektów we wszystkich omawianych subregionach województwa mazowieckiego. 
Warto zwrócić uwagę, że największą wartością projektów realizowanych w ramach RIT charakteryzuje się subregion płocki. W tym subregionie realizowane są dwie znaczące inwestycje: „Budowa trasy północno-zachodniej miasta Płocka” i „Rozwój systemu zrównoważonej mobilności miejskiej na terenie Obszaru Funkcjonalnego Miasta Płocka", których łączna wartość wynosi około $200 \mathrm{mln}$ zł. W subregionie ciechanowskim aż 75\% stanowią umowy dotyczące projektów z zakresu infrastruktury drogowej. Ponadto, każdy subregion wykazuje zróżnicowane potrzeby, co tym samym przekłada się na realizację inwestycji w najbardziej pożądanych obszarach.

\section{Podsumowanie}

Niniejszy artykuł jest podsumowaniem dotychczasowej realizacji projektów RIT w subregionie ostrołęckim. Artykuł obejmuje również zestawienie podpisanych umów w poszczególnych subregionach województwa mazowieckiego. Na podstawie przeprowadzonej analizy można sformułować następujące wnioski:

1. RIT jest mechanizmem stworzonym przez Samorząd Województwa Mazowieckiego, wspierającym rozwój subregionów poprzez realizację inwestycji, które stanowią odpowiedź na zidentyfikowane problemy i potrzeby tych obszarów. Na przykładzie subregionu ostrołęckiego można stwierdzić, że wdrażanie instrumentu RIT na tym obszarze wpływa pozytywnie na jego rozwój.

2. W Planie Inwestycyjnym dla Miasta Ostrołęi i subregionu ostrołęckiego przewidziano realizację 46 inwestycji. Łącznie zostało podpisanych 26 umów, z czego zrealizowano 12 projektów, a 14 jest w trakcie realizacji. Projekty zrealizowane stanowią ponad $46 \%$ wszystkich podpisanych umów w subregionie ostrołęckim.

3. Największa liczba inwestycji w subregionie ostrołęckim dotyczy działania 7.1 Infrastruktura drogowa - 9. Stanowią one prawie 35\% wszystkich projektów.

4. Powiat wyszkowski wyróżnia się pod względem największej liczby realizowanych projektów na tle subregionu - jest ich 8, wśród których 5 zostało już zakończonych.

5. W subregionach ciechanowskim, ostrołęckim, płockim, radomskim i siedleckim podpisanych zostało łącznie 98 umów na realizację inwestycji. Największa ich liczba (aż 42) dotyczy działania 7.1 Infrastruktura drogowa. Stanowi to prawie $43 \%$ wszystkich projektów w subregionach.

6. Subregion ostrołęcki dominuje w liczbie podpisanych umów na realizację inwestycji -26. Stanowi to ponad $1 / 4$ wszystkich projektów w analizowanych subregionach województwa mazowieckiego. Istotne jest również, że zrealizowane i ujęte do realizacji projekty na obszarze subregionu ostrołęckiego są najbardziej zróżnicowane i odnoszą się do wielu dziedzin.

7. Funkcjonowanie instrumentu RIT w kolejnych perspektywach finansowych z pewnością przyczyniłoby się do dalszego wzmacniania procesów rozwojowych na obszarach wymagających interwencji. 


\section{Literatura}

Plan Inwestycyjny dla Miasta Ostrołęi i subregionu ostrołęckiego - przyjęty Uchwałą nr 951/347/18 Zarządu Województwa Mazowieckiego z dnia 12 czerwca 2018 r. zmieniająca uchwałę w sprawie przyjęcia dokumentu pn.: „Plan Inwestycyjny dla Miasta Ostrołęki i Subregionu Ostrołęckiego".

Plan Rozwoju Lokalnego Powiatu Ostrołęckiego na lata 2016-2020 - przyjęty Uchwałą nr XV/103/2016 Rady Powiatu w Ostrołęce z dnia 8 stycznia 2016 r.

Słupińska M., 2013, Rozwój ukierunkowany terytorialnie w nowej polityce spójności, Acta Universitatis Lodziensis, Folia Economica, 289, s. 9.

Strategia - Program Rozwoju Powiatu Wyszkowskiego do roku 2025 - przyjęta Uchwałą nr XVII/112/2015 Rady Powiatu w Wyszkowie z dnia 30 grudnia 2015 r.

Strategia Rozwoju Powiatu Przasnyskiego na lata 2008-2020 - przyjęta Uchwałą nr XVII/130/08 Rady Powiatu Przasnyskiego z dnia 27 maja 2008 r.

\section{Strony internetowe}

www.funduszedlamazowsza.eu

www.infoprzasnysz.com

www.makowonline.pl

www.mapadotacji.gov.pl

www.ostrowmaz.pl

www.powiat-makowski.pl

www.powiat-wyszkowski.pl

www.szpitalprzasnysz.pl

www.to.com.pl

www.wyszkow.pl

\section{Inne źródła}

Dane z Departamentu Rozwoju Regionalnego i Funduszy Europejskich Urzędu Marszałkowskiego Województwa Mazowieckiego. 


\title{
Słownik
}

EFRR - Europejski Fundusz Rozwoju Regionalnego

EFS - Europejski Fundusz Społeczny

OSI - Obszary Strategicznej Interwencji

RIT - Regionalne Inwestycje Terytorialne

RPO WM 2014-2020 - Regionalny Program Operacyjny Województwa Mazowieckiego

na lata 2014-2020

SPZZOZ - Samodzielny Publiczny Zespół Zakładów Opieki Zdrowotnej

SPZOZ-ZZ - Samodzielny Publiczny Zakład Opieki Zdrowotnej - Zespół Zakładów

ZIT - Zintegrowane Inwestycje Terytorialne

Implementation of Regional Territorial Investments on the example of the Ostrołęka subregion

\begin{abstract}
This article analyses the state of implementation of projects within the Regional Territorial Investments (RIT) on the example of the Ostrołęka subregion. RIT is a new financing mechanism proposed by the self-government of Mazovia Voivodeship for the financial perspective 2014-2020. It is designed to support the development of areas requiring support and to strengthen their potentials through the development of socio-economic functions. This mechanism was created as a result of a change in the model of the cohesion policy of the European Union, which is to be territorially oriented.

The first part of the article presents basic information about the RIT mechanism and the way of its implementation in Mazovia Voivodeship. Next, a short description of the Ostrołęka subregion is presented, containing information about the potential and investment needs of the area identified in the Investment Plan for the City of Ostrołęka and the Ostrołęka subregion. The further part of the article presents data obtained from the Department of Regional Development and European Funds of The Office of the Marshal of the Mazowieckie Voivodeship, the information contained in the Investment Plan for the City of Ostrołęka and the Ostrołęka subregion and other available sources. The data were used to summarize the current implementation of projects under the mechanism in the Ostrołęka subregion. Moreover, the subregions of Mazovia Voivodeship were compared in terms of the total number and value of signed contracts for co-financing of planned projects.

The results of the analysis showed that the functioning of the RIT is beneficial both to the Ostrołęka subregion and to entire Mazovia Voivodeship. This mechanism supports the development of areas in various fields, such as road infrastructure, preparation of areas for economic activity, revitalisation and protection of cultural heritage, health infrastructure and low emission reduction. The functioning of the mechanism in the next financial perspectives would certainly contribute to further strengthening of development processes in the subregions of Mazovia Voivodeship.
\end{abstract}

Key words: Regional Territorial Investments, Investment Plan, Ostrołęka subregion 
Justyna Klimkowska, absolwentka Uniwersytetu Warmińsko-Mazurskiego w Olsztynie, pracownik samorządowy, kontakt: Mazowieckie Biuro Planowania Regionalnego w Warszawie, Oddział Terenowy w Ostrołęce, ul. Piłsudskiego 38, 07-410 Ostrołęka, e-mail:jklimkowska@mbpr.pl

Justyna Klimkowska, a graduate of the University of Warmia and Mazury in Olsztyn, public administration employee, contact: Mazovian Office for Regional Planning in Warsaw, Branch office in Ostrołęka, ul. Piłsudskiego 38, 07-410 Ostrołęka, e-mail:jklimkowska@mbpr.pl

Katarzyna Pawłowska, absolwentka Uniwersytetu Warmińsko-Mazurskiego w Olsztynie, pracownik samorządowy, kontakt: Mazowieckie Biuro Planowania Regionalnego w Warszawie, Oddział Terenowy w Ostrołęce, ul. Piłsudskiego 38, 07-410 Ostrołęka, e-mail: kpawlowska@mbpr.pl Katarzyna Pawłowska, a graduate of the University of Warmia and Mazury in Olsztyn, public administration employee, contact: Mazovian Office for Regional Planning in Warsaw, Branch office in Ostrołęka, ul. Piłsudskiego 38, 07-410 Ostrołęka, e-mail: kpawlowska@mbpr.pl 